\title{
Floral Biology Studies in Certain Lesser Known Species of Jasmine (Jasminum spp.)
}

\author{
J. Lakshmi ${ }^{*}$ and M. Ganga ${ }^{2}$ \\ ${ }^{1}$ Department of Floriculture and Landscaping, Tamil Nadu Agricultural University, \\ Coimbatore - 641 003, Tamil Nadu, India \\ ${ }^{2}$ (Horticulture), Horticultural Research Station (TNAU), Ooty - 643 001, Tamil Nadu, India \\ *Corresponding author
}

A B S T R A C T

\begin{tabular}{|l|}
\hline Ke y w o r d s \\
Jasminum spp., \\
Jasminum \\
calophyllum, \\
J. flexile, \\
J. multiflorum, \\
J. nitidum, \\
J. rigidum, Year \\
round flowering, \\
Fruit set. \\
\hline Article Info \\
\hline $\begin{array}{l}\text { Accepted: } \\
23 \text { June } 2017 \\
\text { Available Online: } \\
10 \text { August } 2017\end{array}$ \\
\hline
\end{tabular}

For the utilization of lesser known jasmine species in crop improvement programmes or for other purposes such as commercial cultivation for its flowers or growing as garden plants, insight on floral biology of the species is an essential prerequisite. Characterization of phenology aids in identification of year-round cultivable species of jasmine promising blooming throughout the year. Floral biology and flowering pattern of five lesser known Jasminum species namely, J. calophyllum, J. flexile, J. multiflorum (Pink), J. nitidum and J. rigidum were documented which can be of immense help for commercial jasmine cultivation as well as for jasmine crop improvement programmes.

\section{Introduction}

Jasmine belongs to the 'Oleaceae' family. The genus Jasminum comprises of around 200 species (Rendle, 1925; Bailey, 1958) which are native to tropical and warm temperate regions of Europe, Asia and Africa. The centers of diversity of jasmine are South Asia and Southeast Asia. India is one of the centers of origin of jasmine.

A critical analysis of these species, however, has revealed the number of true species to be only 89, of which 40 inhabit the Indian subcontinent (Veluswamy et al., 1975).
Among the diverse species of Jasminum, only three species (J. sambac, J. grandiflorum, $J$. auriculatum) have attained commercial significance (Rimando, 2003; Green and Miller, 2009). J. multiflorum (Syn: J. pubescens) is commercially cultivated to some extent in Karnataka but not in Tamil Nadu.

Reports indicate that many other species also possess considerable economic potentials (Raman et al., 1969). The popular and widely cultivated jasmine types namely, J. sambac, $J$. 
auriculatum and J. grandiflorum are categorized as commercial species and the other species as lesser known species (Ganga et al., 2015).

The present study was undertaken with the objective of understanding the floral biology of lesser known jasmine species for possible use in commercial floriculture, enrichment of genetic resources for crop improvement endeavours in jasmine and to understand the relationship between the timing of life-cycle events and seasonal climatic patterns (i.e. phenology) which is a fundamental biological process in both natural and managed systems. Phenology is a major driver in determining population dynamics and species interactions (Schwartz 2003).

\section{Materials and Methods}

Five lesser known species of jasmine viz., $J$. calophyllum, J. flexile, J. multiflorum (Pink flowered type) [referred to hereafter as $J$. multiflorum (Pink)], J. nitidum and J. rigidum were employed in the present study. Plants of these species were grown in open field under uniform cultural conditions. Observations were recorded on seventeen parameters namely, flower diameter $(\mathrm{cm})$, corolla tube length $(\mathrm{cm})$, calyx type, mature flower bud colour, open flower colour, number of whorls of corolla, number of petals per flower, number of pistils, pistil type, stigma tip, number of stamens, length of stamen $(\mathrm{cm})$, ovary type, year-round flowering behaviour, flowering pattern, fruit setting potential and season of fruit set. The flower yield was assessed by recording the daily flower yield, based on which the month-wise and annual flower yields were computed.

\section{Results and Discussion}

Knowledge of the floral biology of Jasminum species is required for designing both crop management as well as crop improvement strategies, in response to the seasonal variations. Observations on the various floral biology parameters of the lesser known Jasminum species are presented in Table 1.

The data indicated that the five species expressed similarity with respect to six parameters and variations with respect to the remaining eleven parameters. The six parameters for which the five species expressed similarity were open flower colour, number of whorls of corolla, number of pistils, ovary type, year-round flowering behaviour and fruit setting potential.

Variations were observed with respect to the flower diameter $(\mathrm{cm})$, corolla tube length $(\mathrm{cm})$, calyx type, mature flower bud colour, number of petals per flower, pistil type, stigma tip, number of stamens, length of stamen $(\mathrm{cm})$, flowering pattern and season of fruit set. Flower diameter of the species ranged between 2.1 and $4.2 \mathrm{~cm}$. J. nitidum had the maximum flower diameter while $J$. flexile had the least.

The mature flower bud colour of $J$. calophyllum and J. flexile was white, whereas the remaining three species namely $J$. multiflorum (Pink), J. nitidum and J. rigidum produced pink tinged buds. Number of stamens was two in all the species with the exception of $J$. rigidum wherein flowers with 2 stamens as well as 3 stamens (in $6.66 \%$ of the sampled flowers) were observed.

In all the species except $J$. multiflorum (Pink), the pistil was exerted, slightly protruding out of the mouth of the corolla tube. Observations made in the present study are in line with earlier reports in jasmine (Srivastava and Karmakar, 1985) wherein floral dimorphism expressing long and short carpel in $J$. pubescence has been mentioned. The tip of the stigma was distinctly bifid in $J$. calophyllum, whereas in the other species it was either undivided or not distinctly divided. 
Table.1 Floral biology studies in certain lesser known species of jasmine (Jasminum spp.)

\begin{tabular}{|c|c|c|c|c|c|c|}
\hline \multirow{2}{*}{$\begin{array}{c}\text { S. } \\
\text { No. }\end{array}$} & \multirow{2}{*}{ Parameters } & \multicolumn{5}{|c|}{ Jasminum species } \\
\hline & & J. calophyllum & J. flexile & J. multiflorum (Pink) & J. nitidum & J. rigidum \\
\hline 1. & Flower diameter(cm) & 2.2 & 2.1 & 3.5 & 4.2 & 3.9 \\
\hline 2. & Corolla tube length & 1.1 & 1.2 & 1.9 & 1.78 & 0.8 \\
\hline 3. & Calyx & Rudimentary & Rudimentary & Well developed & Well developed & Well developed \\
\hline 4. & Mature flower bud colour & White & White & Pink & Pink & Pink \\
\hline 5. & *Open flower colour & White & White & White & White & White \\
\hline 6. & *Number of whorls of corolla & 1 & 1 & 1 & 1 & 1 \\
\hline 7. & Number of petals per flower & 7 & 6 & 8 & 11 & 10 \\
\hline 8. & *Number of pistils & 1 & 1 & 1 & 1 & 1 \\
\hline 9. & Pistil type & Exerted & Exerted & Inserted & Exerted & Exerted \\
\hline 10. & Stigma tip & Distinctly bifid & Undivided & Undivided & Not distinctly divided & Not distinctly divided \\
\hline 11. & Number of stamens & 2 & 2 & 2 & 2 & $2-3$ \\
\hline 12. & Length of stamen $(\mathrm{cm})$ & 1.26 & 1.3 & 1.4 & 1.3 & 1.3 \\
\hline 13. & *Ovary type & Bilocular & Bilocular & Bilocular & Bilocular & Bilocular \\
\hline 14. & *Year-round flowering & Present & Present & Present & Present & Present \\
\hline \multirow[t]{4}{*}{15.} & \multicolumn{6}{|c|}{ Flowering pattern } \\
\hline & (i) Peak flowering & April- Oct & Aug-April & Sept-Dec & August-April & March-June \\
\hline & (ii) Lean flowering & Nov-Feb & Jun-July & Jan-April & May- July & July-Dec \\
\hline & (iii) No flowering & - & May & - & - & Jan- Feb \\
\hline 16. & *Fruit setting potential & Present & Present & Present & Present & Present \\
\hline 17. & Season of fruit set & $\begin{array}{c}\text { Throughout the } \\
\text { year }\end{array}$ & $\begin{array}{l}\text { Throughout the year; } \\
\text { profuse during Dec - } \\
\text { Mar }\end{array}$ & $\begin{array}{l}\text { Throughout the year; } \\
\text { profuse during Sept - } \\
\text { Dec }\end{array}$ & $\begin{array}{c}\text { Sparsely present } \\
\text { during Sept - } \\
\text { December } \\
\end{array}$ & $\begin{array}{l}\text { Sparsely present } \\
\text { during June-Sept }\end{array}$ \\
\hline
\end{tabular}

* Parameters for which uniformity was observed for all the 5 species

Table.2 Month-wise flower yield (g/plant) of jasmine species

\begin{tabular}{|c|c|c|c|c|c|c|c|c|c|c|c|c|c|c|}
\hline \multirow{2}{*}{$\begin{array}{c}S . \\
\text { No. }\end{array}$} & \multirow{2}{*}{ Jasminum spp. } & Jun & Jul & Aug & Sep & Oct & Nov & Dec & Jan & Feb & Mar & April & May & \multirow{2}{*}{$\begin{array}{c}\text { Annual Yield } \\
\text { (g/plant) }\end{array}$} \\
\hline & & 2016 & 2016 & 2016 & 2016 & 2016 & 2016 & 2016 & 2017 & 2017 & 2017 & 2017 & 2017 & \\
\hline 1. & J. calophyllum & 87.68 & 46.39 & 28.97 & 15.43 & 8.23 & 16.26 & 14.16 & 93.33 & 73.89 & 153.73 & 115.82 & 198.00 & 851.89 \\
\hline 2. & J. flexile & 26.98 & 42.89 & 56.98 & 72.36 & 62.32 & 50.64 & 62.22 & 73.56 & 80.12 & 92.10 & 80.39 & 46.91 & 747.47 \\
\hline 3. & J. multiflorum (Pink) & 43.21 & 47.32 & 58.90 & 112.36 & 162.09 & 173.65 & 180.34 & 74.39 & 50.21 & 68.63 & 38.10 & 20.38 & 1029.58 \\
\hline 4. & J. nitidum & 112.49 & 72.56 & 69.32 & 48.45 & 58.39 & 34.79 & 24.02 & 79.33 & 206.25 & 270.64 & 297.30 & 140.73 & 1414.27 \\
\hline 5. & J. rigidum & 5.86 & 1.04 & 6.68 & 5.36 & 3.86 & 1.14 & 1.89 & 1.23 & 1.04 & 7.34 & 8.57 & 11.13 & 55.14 \\
\hline \multicolumn{2}{|c|}{ Grand mean } & 55.24 & 42.04 & 44.17 & 50.79 & 58.98 & 55.30 & 56.53 & 64.37 & 82.30 & 118.49 & 108.04 & 83.43 & 819.67 \\
\hline \multicolumn{2}{|c|}{ SED } & 1.21 & 0.56 & 0.76 & 1.28 & 2.38 & 1.68 & 1.81 & 0.59 & 1.95 & 2.16 & 3.34 & 2.08 & 10.74 \\
\hline \multicolumn{2}{|c|}{$\mathrm{CD}(\mathrm{P}=0.05)$} & 2.80 & 1.29 & 1.75 & 2.95 & 5.50 & 3.89 & 4.17 & 1.37 & 4.50 & 4.98 & 7.70 & 4.80 & 24.77 \\
\hline \multicolumn{2}{|c|}{$\mathrm{CD}(\mathrm{P}=0.01)$} & 4.07 & 1.87 & 2.54 & 4.30 & 8.00 & 5.65 & 6.06 & 1.99 & 6.55 & 7.24 & 11.20 & 6.98 & 36.04 \\
\hline
\end{tabular}


Fig.1 Monthly flower bud yield per plant (g) of lesser known jasmine species

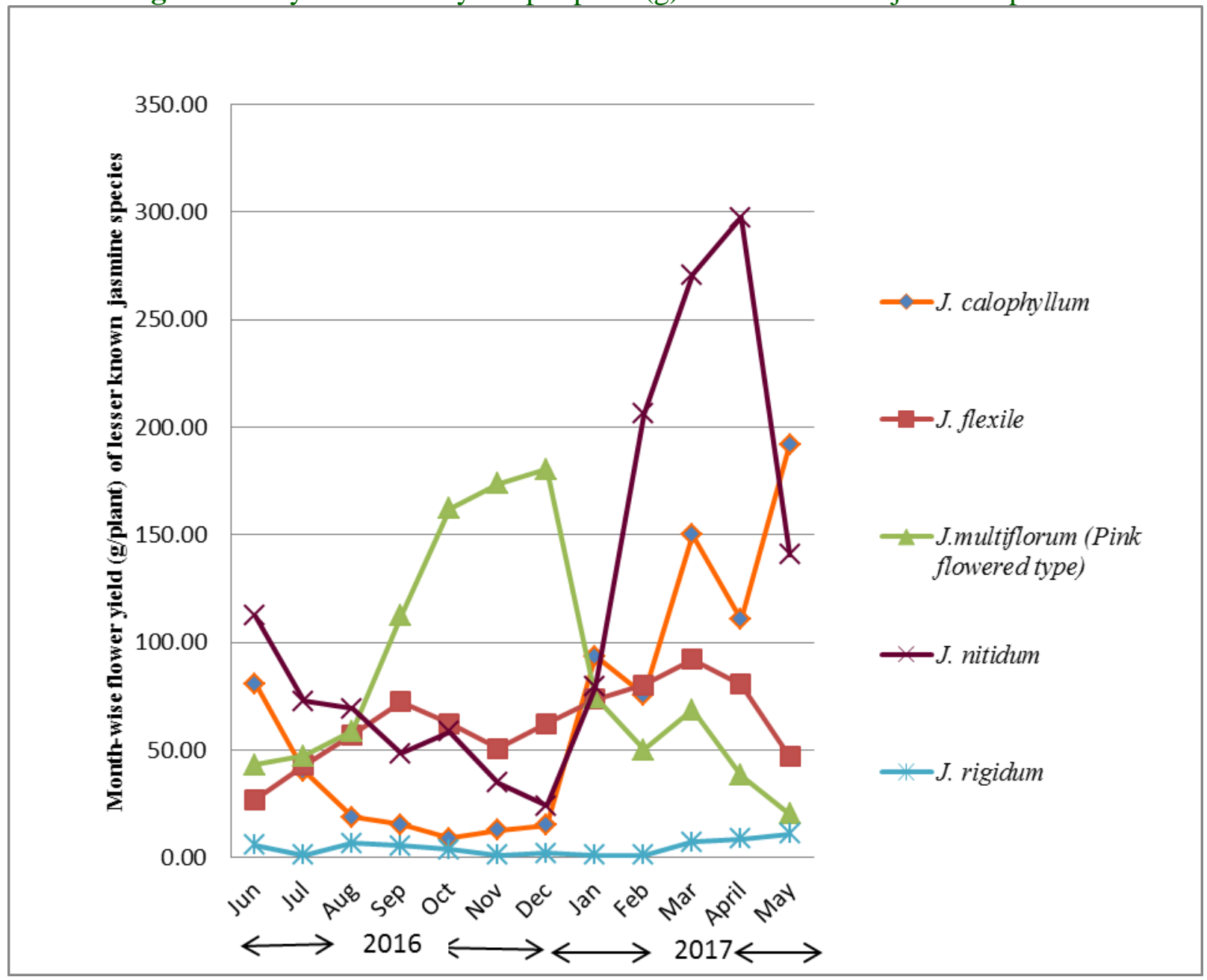

Season affects the flowering duration in the commercial species viz., J. sambac, J. auriculatum and $J$. grandiflorum. The seasonal variation of flowering in Jasminum species is due to the variations in photothermal units which profoundly influence flowering. Similar findings were reported by Raman (1973) and Nedumaran (1977). It could be observed in the present study that all the five lesser known species of jasmine flowered throughout the year. This observation is in corroboration with that of Raman et al., (1969) who noted year round flowering in $J$. pubescens, $J$. flexile, $J$. calophyllum and J. rigidum. He opined that this year-round flowering behaviour was a promising feature which would make these species ideal for cultivation both in fields and home gardens to ensure continuity of flower production all the year round.

Similar observations have also been reported recently (Ganga et al., 2015) in the underutilized jasmine species $J$. nitidum in addition to the above mentioned lesser known species, leading to the scope of cultivating $J$. nitidum and J. multiflorum (Pink) as potential alternative jasmine types, to bridge the gap of low productivity and seasonal variability prevalent in the commercially cultivated species during off-season. Year-round flowering trait of the lesser known jasmine species also offers the possibility to enhance the germplasm resources for crop 
improvement. Prolonged blooming period in the off season offers the possibility to program planned crossing strategies to be employed in the breeding pursuits.

The data pertaining to flower yield of the Jasminum species evaluated are furnished in Table 2 \& Fig 1. Among the five lesser known species, $J$. nitidum recorded the highest annual flower yield/ plant of (1414.27g). This was followed by $J$. multiflorum (Pink) which recorded an annual yield/plant of $1029.58 \mathrm{~g}$. The lowest annual flower yield/plant of $55.14 \mathrm{~g}$ was recorded in J. rigidum.

With respect to seed setting, it was observed in the present study that though all the five species had seed setting potential, J. flexile and $J$. multiflorum (Pink) were profuse seed setters. This potential can be exploited in in hybridization programmes, wherein such species can be ideal female parents. Knowledge of the flowering and seed setting patterns of the jasmine species can be effectively utilized in expediting planned crossing schemes.

\section{References}

Bailey, L.H. 1958. Manual of cultivated plants. Pub: Macmillan and Co., New York.

Ganga, M., Madhumalar, P., Jawaharlal, M. and Ranchana, P. 2015. Assessment of the horticultural significance of lesser known jasmine (Jasminum spp.) wealth. Journal of Ornamental Horticulture, 18 (1\&2): 17-24.
Monika Patel. 2013. Analysis of growth and yield performance of certain commercial jasmine (Jasminum spp.) varieties. M.Sc. Thesis submitted to Tamil Nadu Agricultural University, Coimbatore- 3.

Neduraman, C. (1977). Effect of different dates of pruning on flower bud formation, growth and yield of flowers of jasmine cv. Parimullai (Jasminum auriculatum Vahl) M.Sc. (Ag) Diss. Tamil Nadu Agric. Univ. Coimbatore.

Raman, K.R. (1973). Studies on some aspects of flowering in Jasminum sambac. Ph.D Diss. Tamil Nadu Agric. Univ. Coimbatore.

Raman, K.R., Shanmugam, A. and Ahmad Sha, H. (1969). Studies on flowering habits and flower yields of some Jasminum species. South Indian Horticulture, 17: 18-27.

Rendle, A.S. 1925, The Classification of flowering plants II, Cambridge Univ. Press, Oxford, England.

Schwartz M. D. 2003, Phenology: an integrative environmental science. Dordrecht, Kluwer Academic Publishers: The Netherlands.

Srivastava, H.C. and Karmakar, P.G. (1985). Distily and morpho economic characters in Jasminum pubescens Willd. Incompatibility Newsletter, No.17: 3233.

Veluswamy, P., Thangaraj, T. and Muthuswamy, S. 1975. A study on germination of seeds of some Jasminum species and clones. South Indian Horticulture, 23: 71-72.

\section{How to cite this article:}

Lakshmi, J. and Ganga, M. 2017. Floral Biology Studies in Certain Lesser Known Species of Jasmine (Jasminum spp.). Int.J.Curr.Microbiol.App.Sci. 6(8): 2811-2815. doi: https://doi.org/10.20546/ijcmas.2017.608.334 